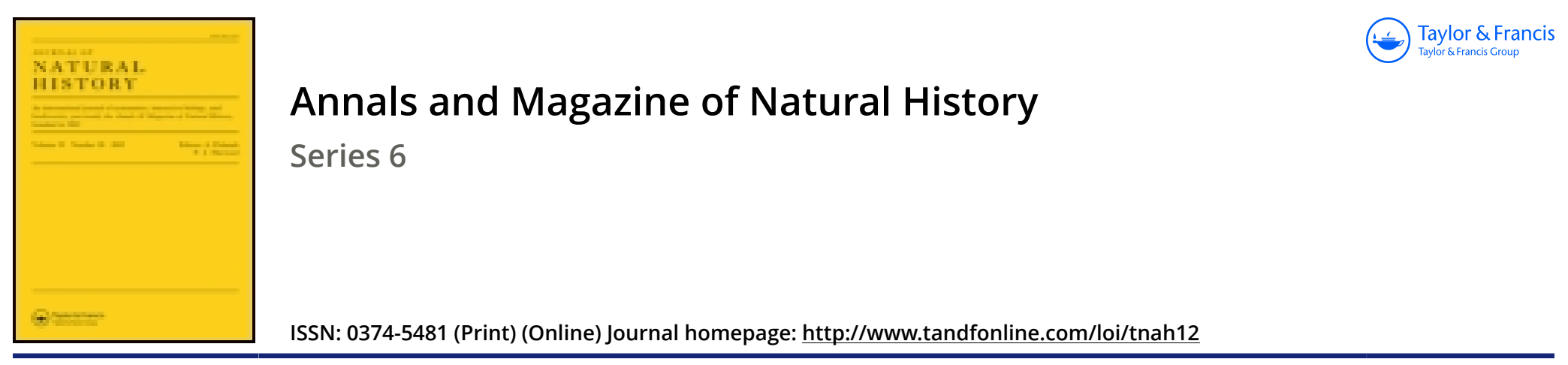

\title{
XXV.- Notes on the species of Phasmidæ collected by Basil Thomson, Esq., in the Louisiade Archipelago
}

\section{W.F. Kirby F.E.S.}

To cite this article: W.F. Kirby F.E.S. (1889) XXV.-Dotes on the species of Phasmidæ collected by Basil Thomson, Esq., in the Louisiade Archipelago , Annals and Magazine of Natural History, 4:21, 229-231, DOI: 10.1080/00222938909460507

To link to this article: http://dx.doi.org/10.1080/00222938909460507

曲 Published online: 12 Oct 2009.

Submit your article to this journal 지

ЏII Article views: 6

Q View related articles $₫$ 


\section{Hemirhamphus, sp.}

Several young specimens of a species of Hemirhamphus cylindrical in shape and only partly covered with small scales on the hind part of the body, with a bright, silvery, welldefined band, were collected by Mr. Styan at Kiu-Kiang on March 27. The determination of these specimens as to species is uncertain at present.

\section{Clupea Reevesii, Rich.}

Mr. Styan collected specimens 30 inches long.

Salanx chinensis, Osbeck.

This species ascends the river to Kiu-Kiang, where Mr. Styan obtained a specimen on March 27.

XXV.-Notes on the Species of Phasmidæ collected by Basil Thomson, Esq., in the Louisiade Archipelago. By W. F. KIrbY, F.E.S., Assistant in Zoological Department, British Museum (Natural History).

In addition to Lepidoptera Mr. Thomson collected a small number of other insects, including some extremely interesting Phasmidx. Among these were three female specimens which I cannot distinguish specifically from the wide-ranging and somewhat variable Eurycantha horrida, Boisd. The smallest of these is of a dark reddish-brown and measures 136 millimetres ( $5 \frac{1}{2}$ inches) in length; it much resembles specimens which we have previously received from Thursday Island. The other two are darker and much larger than any specimens previously in the collection of the British Museum; the largest measures 183 millim. (about $7 \frac{1}{2}$ inches) in length and 25 millim. (an inch) across the thorax. The small specimen is from Goodenough Island and the two large ones from Rossel Island.

There is also a series of both sexes of a small Promachus taken on Sudest Island, Oct. 10, 1888, and a much larger female, taken on Rossel Island on Oct. 18. These have considerable general resemblance, and I might have considered the small specimens to be only the immature form of the larger one, but that the proportions of the tarsi are very different. 


\section{Promachus spinosus, sp. n.}

Long. corp. 91 millim.

Female.-Reddish brown; antennæ darker, about as long as the head and thorax; head fully as long as the prothorax; a groove on the hinder half, curving off into two shallower depressions in front to the base of the antennæ; the head is covered with short spines or warts above, and there is a broad slightly dentated spine on each side about the middle; pro. thorax with two broad slightly diverging spines on an elevation in front and a strong ridge with a bifid elevation in the middle behind; there is also a row of three broad spines on each side and some smaller ones; the hindermost is twice as long as the others and dentated; mesothorax with a large elevation at one third of its length, in front of which are three diverging carinæ; behind this is a strong carina rising into a transverse ridge behind, the middle of which is occupied by another bifid prominence; the surface is studded with small scattered warts, and there are three large spines in front above the lateral line and two more below, above the middle coxæ, the larger ones being again surrounded and studded with shorter spines and warts; metathorax with a strong carina and a large spine on the middle and behind ; below the median line there is a large cluster of spines in front of the hind coxæ; abdomen with the first six segments transverse, the remainder tapering; with a longitudinal granular carina, rising into a simple spine at the extremity of each segment, which slopes laterally to the base of a short spine on each side; near the front of each segment is an acute oblique spine on each side, and along the lateral line runs a row of short spines. On the eighth segment the terminal spines on the median line end with a strong raised ridge extending along nearly the whole length of the segment. The median spines, except the last ridge, are usually marked with black, and the ovipositor is also black. The legs are strongly ridged and are moderately spined along the carine on the femora and tibia. The femora, except at the base and tip, and a great part of the tibiæ and tarsi are blackish. Body beneath testaceous, nearly smooth, with only a row of spiny warts running along each side of the mesothorax and abdomen.

Legs rather short, femora rather shorter than the tibiæ. First four joints of the tarsi short, diminishing in length, the fifth as long as all the others. Antennæ slightly pilose; scape as long as the third joint, but much thicker than the short second joint, which again is thicker than the third.

Hab. Rossel Island, Oct. 18. 
The complicated spines of this insect are very difficult to describe. It is not very similar to any previously described species with which I am acquainted.

\section{Promachus insularis, sp. $\mathrm{n}$.}

$\delta^{\star}$, long. corp. 30 millim.; $q, 47-50$ milim.

Head and prothorax of about equal length; mesothorax about three times as long as broad and narrower than the metathorax, which is rather longer than broad; abdomen with the first six segments transverse, broader than long; the terminal segments narrower, raised and carinated. Antennæ a little longer than the head and thorax. Colour brown, slightly inclining to red in the male. Spines arranged as follows:-Merian line: head with a pair of spines at the back; prothorax with two pairs; mesothorax with three pairs; metathorax with two single spines; and abdomen with a single spine at the extremity of each segment and diminishing in size hindwards. Lateral spines: mesothorax with four on each side; metathorax with one on each side; female with a row of spines on each side of the abdomen,

Femora with all the carinæ dentated, also the tibiæ slightly in the female, especially at the base; all the coxæ spined at the base (at least in the female), those on the hind coxæ the largest. First joint of tarsi as long as the remainder; first joint of antennæ long, broad, and compressed.

Male with the cerci small, pincer-like; female with the upper spine extending for one third of its length beyond the operculum.

Hab. Sudest Island, Oct. 10, 1888.

Allied to Acanthoderus (?) hystrix, Kaup.

XXVI.-On some new or little-knoun Species of Libellulinæ from Jamaica in the Dublin Museum of Science and Art. By W. F. Krrby, F.E.S., Assistant in Zoological Department, British Museum (Natural History).

The Dublin Museum of Science and Art contains a valuable series of insects of all orders from Jamaica, and I have lately had the opportunity, through the courtesy of the Keeper, Dr. Scharff, of examining some of the Odonata, among which I found several species of extreme interest, which form the subject of the present paper. 